\title{
共通バッファ制限付きジョブショップスケジューリング 問題の解法*
}

傅貴 ${ }^{\dagger}$. 趙勇 $\ddagger$ 三宮 信夫 $\S$

\author{
A Method for Solving Jobshop Scheduling Problems \\ with Limited Common Buffers*
}

Gui $\mathrm{FU}^{\dagger}$, Yong ZHAO $\mathrm{ZH}^{\ddagger}$ and Nobuo SANNOMIYA ${ }^{\S}$

\begin{abstract}
A new jobshop scheduling problem with limited common buffers is dealt with in this paper. The standard genetic algorithm is not applicable to the present problem for deadlocks led by buffer constraints. A new algorithm is proposed by combining the genetic algorithm (GA) with a semi-active decoding which avoids deadlocks and satisfies the buffer constraints. Some benchmark problems appending with buffer constraints are tested by both the proposed GA and the multi-start local search method (MLS). Computation results show that the proposed GA outperforms MLS well. Computation is also made by varying the number of common buffers. These results are compared among the available results of the no-buffer jobshop problem and the normal jobshop problem. Consequently the results of the proposed GA are satisfactory.
\end{abstract}

\section{1.はじめに}

多品種少量生産の時代に拈いて，製造現場は様々な製 造要求に対応できることが求められている。機械の使用 順序が製品によって異なるジョブショップ工程では，定 められた機械の物理条件のもとで, 製造工程途中で仕掛 品を一時的に収納するバッファが通常設置されている。 これまでの多くの研究では，ごのようなバッファに対し て制約条件などを考慮することなく，バッファ容量は無 限であると仮定されてきた $[1,2]$. しかしバッファの使用 に大きいコストが掛かる製造現場や限られたバッファし か使えない現場では，バッファの使用を最小限に抑える ことや，限られたバッファ条件の中で最大限の製造効率

* 原稿受付 2003 年 6 月 20 日

$\dagger$ 京都工芸繊維大学 大学院 工芸科学研究科 Graduate School of Science and Technology, Kyoto Institute of Technology; Matsugasaki, Sakyo ward, Kyoto city, Kyoto 606-8585, JAPAN

ま (株) セゾン情報システムズ システム技術センターSystem Technology Center, Saison Information Systems Co., LTD; Higashi-Ikebukuro, Toshima ward, Tokyo 1706021, JAPAN

$\S$ 京都工芸繊維大学 名誉教授 Professor Emeritus of Kyoto Institute of Technology; Matsugasaki, Sakyo ward, Kyoto city, Kyoto 606-8585, JAPAN

Key Words: jobshop scheduling, limited buffers, genetic algorithm, deadlock, reference chain graph.
を実現することが求められている．本研究はこのような バッファ制限付きジョブショップスケジューリング問題 を対象にしている。

ジョブショップ問題はNP 困難な問題として知られ，こ れまで多く研究されてきた。この問題にバッファ無しの 制約を付加した問題に対しては，Ramaswamyら [3] が 整数計画法, Liljenvell[4,5]がオートマトンやペトリネッ トにA*アルゴリズムを用いた方法，またMatiら [6] や Zhao ら [7], 傅ら [8] はタブサーチや遺伝アルゴリズム (GA) に基づく方法を提案している. 一方、待ち時間無 しジョブショップ問題に対しては, Brizuelaら [9]が GA による解法を示した。ささらに繰返し型生産で各機械には それぞれ専用のバッファが存在し，バッファ容量に制限 があるスケジューリング問題に対して，玉置ら $[10,11]$ は 混合整数計画問題やタイムペトリネットモデルとして扱 い，分離グラフや分枝限定法などを用いた解法を示した。 しかし機械間で共通に利用可能なバッファが存在し，そ のバッファに制限がある問題を扱ったものはなかった。

本研究は，まず共通バッファ制限付きジョブショップ 問題を定義する。次に問題特有のデッドロックを回避し たセミアクティブなデコーディング手法を実装した遺伝 アルゴリズムを提案する。また提案アルゴリズムを用い て，いくつかのベンチマーク問題に共通バッファの制限 を加えた問題を作成してその解計算を行う。 また, 単純 多スタート局所探索法 (MLS) を適用して, 提案アルゴ 
リズムと結果を比較する，その結果，本提案手法はバッ ファ制限付き問題に対して，大変優れた結果を示すこと がわかった。さらに，バッファ制限無し問題やバッファ 無し問題に対して提案された方法で得られている結果と 比較した結果, 本提案手法で得られている結果が適切で あることがわかった．これらの計算結果より，規模の比 較的大きい問題でも，少ないバッファ数でバッファ制限 無し問題の最適值に近い目的関数值が得られることが示 された。

\section{2. 問題の記述}

$N$ 個のジョブと $M$ 台の機械が存在する. ジョブ $i に Y_{i}$ 個の作業 $\rho_{i j}$ が存在する. ここで, $i \in \mathbf{P}:=\{1,2, \cdots, N\}$, および $j \in \mathbf{Q}_{i}:=\left\{1,2, \cdots, Y_{i}\right\}$ とする. 作業 $\rho_{i j}$ の使用機 械および処理時間はそれぞれ $\mu_{i j}$ および $t_{i j}$ である。作 業 $\rho_{i j}$ は $j$ のさい順に処理されるものとする.さらに, 各作業は中断が許されないとする．仕掛けジョブは処理 中作業が終了後，直前に使用した機械で待機するか，次 の処理機械あるいは空の共通バッファへ移るものとする. バッファはジョブを基本単位として 1 個のバッファには 1 個のジョブを収納するものする，バッファの総個数を $B F$ とする.

ここで，いくつかの変数を定義する. 作業 $\rho_{i j}$ の実行開 始時刻を $s_{i j}$ とする. $\alpha_{i j}(t)$ は, 作業 $\rho_{i j}$ から作業 $\rho_{i j+1}$ に移る間，時刻 $t$ におけるジョブ $i$ のバッファ使用状態 を表し, 次式で定義する。なお, 時刻 $t$ は離散量とする.

$$
\alpha_{i j}(t)=\left\{\begin{aligned}
1 & \text { 時刻 } t \in\left(s_{i j}+t_{i j}, s_{i j+1}\right) \\
\text { においてジョブ } i \text { が } & \text { バッファを使用するとき } \\
& \text { 時刻 } t \in\left(s_{i j}+t_{i j}, s_{i j+1}\right) \\
\text { においてジョブ } i \text { が } & \text { バッファを使用しないとき } \\
& \forall i \in \mathbf{P} . \forall j \in \mathbf{Q}-\left\{Y_{i}\right\}
\end{aligned}\right.
$$

$\beta_{i j}$ は作業 $\rho_{i j}$ から作業 $\rho_{i j+1}$ の間, ジョブ $i$ がバッファ に滞留した時間を表し，次式で与えられる。

$$
\beta_{i j}=\sum_{t \in(0, \infty)} \alpha_{i j}(t), \quad \forall i \in \mathbf{P} ; \forall j \in \mathbf{Q}_{i}-\left\{Y_{i}\right\}
$$

目的は次式で表される makespan $c_{\max }$ の最小化であ る.よって, 本問題は次のように表される.

$$
\operatorname{minimize} c_{\max }=\max _{i \in \mathbf{P}}\left\{s_{i Y_{i}}+t_{i Y_{i}}\right\}
$$

subject to

$$
\begin{aligned}
& s_{i j} \geq 0, \quad \forall i \in \mathbf{P} ; \forall j \in \mathbf{Q}_{i} \\
& s_{i j}+t_{i j}+\beta_{i j}<s_{i j+1}, \quad \forall i \in \mathbf{P} ; \forall j \in \mathbf{Q}_{i}-\left\{Y_{i}\right\} \\
& \text { If } \mu_{i j}=\mu_{q r} \text { then } \\
& s_{i j}+t_{i j}<s_{q r} \text { or } s_{q r}+t_{q r}<s_{i j} \\
& \forall i, q \in \mathbf{P} ; i \neq q ; \forall j \in \mathbf{Q}_{i} ; \forall r \in \mathbf{Q}_{q}
\end{aligned}
$$

$$
\begin{aligned}
& \text { If } \mu_{i j}=\mu_{q r} \text { and } s_{i j}>s_{q r} \text { then } \\
& s_{i j}>s_{q r+1}-\beta_{q r} \\
& \forall i, q \in \mathbf{P} ; i \neq q ; \forall j \in \mathbf{Q}_{i} ; \forall r \in \mathbf{Q}_{q}-\left\{Y_{q}\right\} \\
& \qquad \sum_{i \in \mathbf{P} ; j \in \mathbf{Q}_{i}-\left\{Y_{i}\right\}} \alpha_{i j}(t) \leq B F, \quad \forall t \in(0, \infty)
\end{aligned}
$$

制約条件について，(4)式および(5)式はそれぞれ作業 開始時刻および作業開始順序の制約を表す。(6) 式は作 業の途中で中断が許されないことを表す。(7) 式は作業 が機械から機械へ移るとき, 移動先の機械が空いている 条件を示す. (8) 式はバッファ数の制限を表す.

なお (5) 式〜 (7) 式は, 等号の付かない条件式となっ ている. 通常各作業の開始や終了にはセットアップタイ ムが必要であるが, 本研究では作業のマシン間移動およ びマシンとバッファ間の移動に掛かる時間は処理時間に 比べて十分に小さいものとして扱う.

\section{3. デッドロック}

共通バッファ制限付きジョブショップ問題には，問題 特有のデッドロック状態が発生することがある。デッド ロック状態に陷ると，以下に述べるように，スケジュー ルは実行不可能になる。

まず二つの機械 $\mu_{i j}$ と $\mu_{q r}$ で稼働中のジョブ $i$ と $q$ (そ れぞれの稼働中の作業は $\rho_{i j}$ と $\left.\rho_{q r}\right)$ が次に使用しようと する機械, すなわち次の稼働予定機械はそれぞれ相手の 機械であるとすれば，(7) 式より次の関係が成り立つ.

$$
\left.\begin{array}{l}
s_{i j+1}>s_{q r+1}-\beta_{q r} \\
s_{q r+1}>s_{i j+1}-\beta_{i j}
\end{array}\right\}
$$

(1) 式および $(2)$ 式による $\beta_{i j}$ の非負条件および $(9)$ 式よ り, $\beta_{q r}$ と $\beta_{i j}$ の少なくとも一方は正の值をとる必要があ る.このとき，仮にすべてのバッファが使用されていて， かつバッファにある任意のジョブの次の稼働予定機械は 機械 $\mu_{i j}$ か $\mu_{q r}$ のどれかであるとする．いま，バッファ内 にあるジョブの中で次の最速稼働予定作業を $\rho_{a b}$ とし， その稼働予定時刻を $T_{a b}$, 稼働予定機械を $\mu_{i j}$ とする.

まず $\beta_{i j}>0$ とする.このとき，ジョブ $i$ がバッファを 使用開始する時刻を $T_{i j}$ とする. ジョブ $i$ がバッファを 使用するためには $T_{i j}>T_{a b}$ でなければならず，一方ジョ ブ $a$ が機械 $\mu_{i j}$ で処理されるには $T_{a b}>T_{i j}$ でなければな らない。これは明らかに矛盾する。

つぎに， $\beta_{i j}=0$ とするならば，ジョブ $i$ がバッファを 使用しないので, 次の稼働予定機械 $\mu_{q r}$ で処理される ことになる. 一方このとき $\beta_{q r}>0$ であるから，ジョブ $q$ がバッファを使用し, その開始時刻を $T_{q r}$ とすれば, $s_{i j+1}>T_{q r}, T_{q r}>T_{a b}$ でなければならない. 一方, 作業 $\rho_{a b}$ が $\mu_{i j}$ で処理されるためには， $T_{a b}>s_{i j+1}$ でなけれ ばならない.ここでも矛盾が生じる。

このような状態をデッドロック状態という．デッドロッ ク状態になると，スケジュールは実行不可能となる，よっ 
て, 共通バッファ制限付きジョブショップ問題の可能解 を生成するには，スケジュール作成時にデッドロック状 態に陥らないように配慮する必要がある。

\section{4. デッドロックの検知}

デッドロックは下記に述べる機械参照ジョブチェーン 図を作成することで，容易に見つけることができる。

Fig.1のようにジョブを節点で表し，あるジョブ (例 えばジョブ $i$ )が他のジョブ(例えばジョブq)の使用機械 が空くのを待っているとき, ジョブ $i$ から $q$ へ有向枝を 描く.このとき, ジョブ $q$ をジョブ $i$ の機械参照ジョブ とよぶ. 同様のことをすべてのジョブに対して行い, 得 られる有向グラフを機械参照ジョブチェーン図とよぶ. 有向枝が出ていない節点を終端ジョブとよぶ．終端ジョ ブは次に必要とする機械が空いているので，直ちにスケ ジュール可能である。な㧍，終端ジョブの次の稼働予定 作業を終端作業とよぶ，機械参照ジョブチェーン図にお いて，有向枝を介してつながっているジョブおよび有向 枝の一部または全部がループを構成している場合，その ジョブ抢よび有向枝をループチェーンとよぶ. Fig. 1 に は二つのループチェーンが存在する.

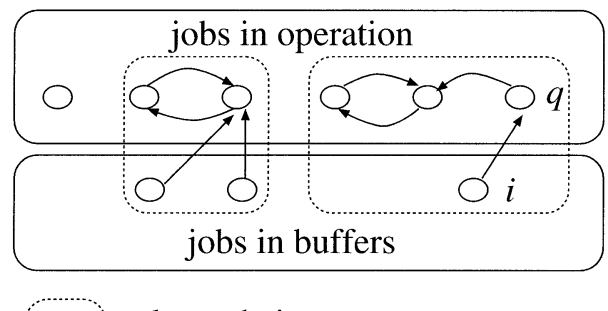

: loop chain

Fig. 1 Machine reference job chain graph $(B F=3)$

全部のバッファが使用されて，かつバッファにあるジョ ブから出ている有向枝がすべてループチェーン上の節点 を指すならば，スケジュールは上に述べたようにバッファ と機械が互いの空きを待つという矛盾した状態に陥って いるので，デッドロックとして検知される．Fig.1は三 つのバッファを持つスケジュールにおけるデッドロック の一例である。

\section{GA による解法}

これまでの研究 $[1,2,7,8]$ で，GA はバッファ制限無し およびバッファ無しジョブショップ問題において, 有効 な解法であることが示されているので，本問題に対して も，GAの適用を試みる。

\section{1 個体表現}

ジョブショップ問題に対して, 種々の個体表現法 [1] が 提案されているが, 本研究では, 作業を当該ジョブのジョ ブ番号で表し, そのジョブ番号の順列で個体の遺伝子型 を表現する。このとき，ジョブ $i$ の部分順列において， $j$ の昇べきの順に $i$ を作業 $\rho_{i j}$ で置き換えることにより，一
意に作業順列が得られる.

4 ジョブ 3 機械問題 ss[3] の個体表現の一例を以下に 示す.

$$
[1,4,4,3,1,2,1,4,3,3,2,2]
$$

このときの作業順列は，次のように得られる。

$\left[\rho_{11}, \rho_{41}, \rho_{42}, \rho_{31}, \rho_{12}, \rho_{21}, \rho_{13}, \rho_{43}, \rho_{32}, \rho_{33}\right.$, $\left.\rho_{22}, \rho_{23}\right]$

後述の例示のために, 問題 ss のパラメー夕を付録 1 に 示す.

\section{2 デコーディング方法}

上記の個体表現を実際の生产現場で用いるスケジュー ルに変換するには，下記のデコーディング法を用いる。

まず，作業のスケジュールとは各作業の機械における 処理開始時刻を定めること, あるいは作業が機械で処理 されるまえに当該のジョブがバッファを使用する場合， そのバッファの使用開始時刻および使用終了時刻を定め ることをいう．作業のスケジュールを行うために，作業 の集合をスケジュールの進行状態に応じて，三つの集合 $A, B$ および $C$ に分ける。集合 $A$ は機械における処理開 始時刻が定まった作業の集合である．集合 $A$ 以外の作業 のうち, 集合 $B$ はバッファにあるジョブの次の処理予定 作業の集合である，集合 $C$ は集合 $A$ および $B$ のいずれ にも入らない作業の集合である。

作業のスケジュールは，作業を集合 $C$ から集合 $A$ か $B$ に，あるいは集合 $B$ から集合 $A$ に移す操作にほかな らない.ここで, (i) 集合 $C$ の作業のうち直前の作業が 集合 $A$ に属する作業，および (ii) 集合 $B$ の作業で構成す る集合をスケジュール候補作業集合 (集合 $O$ ) とよぶ.な お，集合 $A$ 中の要素はスケジュールされた順番で順序付 けられているとする。

個体表現をスケジュールに変換する基本的な手順を Fig. 2 に示す。それはつぎの通りである。まずデコーディ ングは与えられた集合 $B$ および $C$ からスケジュール候 補作業集合 $O$ を生成する。つぎに，バッファや機械の空 状態に依存して，スケジュール方法を三つのケースに分 ける。もしもバッファが空いているなら，集合 $O$ より 一定の優先則に沿って，スケジュール対象作業を決定す る. 対象作業の稼働予定機械が空いているなら, 直ちに その機械にスケジュールする (Fig. 2(a)のケース). 機械 が空いていないなら，機械を使用しているジョブをその 処理中作業が処理終了後にバッファに退避させ，対象作 業を機械にスケジュールする (Fig. 2(b)のケース).もし もバッファが空いていないなら, 集合 $O$ の終端作業で構 成する集合 $S$ より一定の優先則に沿って, スケジュール 対象作業を決定する。そして，対象作業を稼働予定機械 にスケジュールする (Fig. 2(c)のケース).

デコーディングの途中でデッドロックが検出された場 


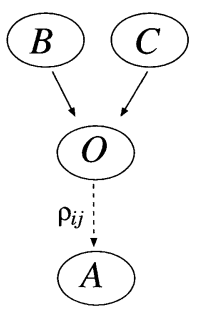

(a)

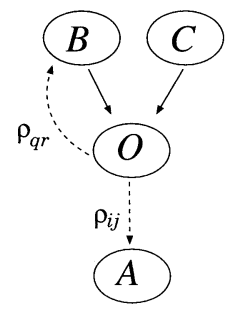

(b)

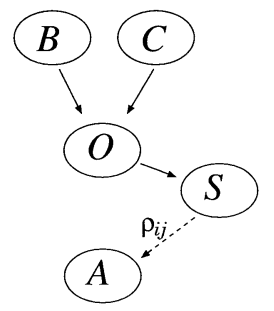

(c) $\rho_{i j}$ : operation to be scheduled in machine $\rho_{q r}$ : operation to be scheduled in buffer

Fig. 2 Three cases for fundamental scheduling procedure 合, 直前のスケジュール操作でスケジュールした作業 (す なわち集合 $A$ の最後の作業, さらにその作業がFig.2(b) のケースによってスケジュールされたなら，バッファに スケジュールされた作業も含めて) を元の集合に戻し，ス ケジュールをやり直すが, この集合 $A$ の最後の作業を次 のスケジュール操作で使用しないようにマスクする。そ の作業のことをマスク作業 $x$ という.

このようにすべての作業が機械にスケジュールされる までに，すなわち集合 $A$ にセットされるまでに，上記 の操作を繰り返すが, 計算時間の節約のために, デッド ロックの発生回数を $n_{r}^{*}$ 回までしか許容しないものとす る。それ以上デッドロックが発生すると，その個体は便 宜上スケジュール不可能として扱う。

集合 $A, B$ および $C$ が与えられている場合，具体的な デコーディングの手順を以下に示す。 な损, 作業 $y$ はデ コーディングが Fig.2 のケース (b) に沿って実行される とき, バッファにセットされる作業 $\rho_{q r}$ とし，それ以外 のケースのとき，NULLとする.

ステップ 1 作業 $x$ および $y$ を NULL とする.デッド ロック発生回数を $n_{r}=0$ とする.

ステップ 2 集合 $B$ 抢よび $C$ より, 集合 $O$ を生成する. 集合 $O$ をもとに, 機械参照ジョブチェーン 図を作成する。

ステップ 3 機械参照ジョブチェーン図でデッドロック 検知をし，デッドロックが検知されれば， ステップ9へ移る。

ステップ 4 空バッファがなければ，ステップ7に移る. 空バッファがあれば，集合 $O$ から一定の優 先則に基づいて, マスク作業 $x$ 以外のスケ ジュール対象作業 $\rho_{i j}$ を決定する。このと き，もしもそのような $\rho_{i j}$ が存在しないな ら, 集合 $A$ の最後の作業 $\rho_{l m}$ 抢よび $\rho_{l m}$ をスケジュールしたときの作業 $y$ を元の集 合に戻し， $x=\rho_{l m}$ とする．ステップ 2 に 移る。 $\rho_{i j}$ が存在するなら，ステップ 5 に 移る。

ステップ $5 \quad \rho_{i j}$ が集合 $O$ の機械参照ジョブチェーン図
の終端作業でなければ，ステップ6に移る. 終端作業ならば，作業を機械にスケジュー ルし，集合 $A$ にセットする. $y=$ NULL と する。ステップ 8 に移る.

ステップ 6 一定の基準に基づいてスケジュール対象 バッファを選出し, $\rho_{i j}$ の機械参照ジョブの 次の処理予定作業 $\rho_{q r}$ を対象バッファにスケ ジュールし，集合 $B$ にセットする. $y=\rho_{q r}$ とする。つぎに， $\rho_{i j}$ を機械にスケジュー ルし，集合 $A$ にセットする．ステップ8に 移る。

ステップ 7 集合 $O$ の機械参照ジョブチェーン図の終 端作業で集合 $S$ を生成し, 集合 $S$ より一 定の優先則に基ついて, 作業 $x$ 以外のスケ ジュール対象作業 $\rho_{i j}$ を決定する。このと き，もしもそのような $\rho_{i j}$ が存在しないな ら, 集合 $A$ の最後の作業 $\rho_{l m}$ および $\rho_{l m}$ をスケジュールしたときの作業 $y$ を元の 集合に戻し， $x=\rho_{l m}$ とする. ステップ 2 に移る， $\rho_{i j}$ が存在するなら， $\rho_{i j}$ を機械 にスケジュールし，集合 $A$ にセットする. $y=$ NULL とする.

ステップ $8 x=$ NULL とする.すべての作業が集合 $A$ にセットされたら，デコーディングを終了 する，そうでなければ，ステップ 2 に移る。

ステップ $9 \quad n_{r}=n_{r}^{*}$ ならば，当該個体をスケジュール 不可能解として, 目的関数を十分大きい值 に設定し, デコーディングを終了する。

ステップ $10 \quad n_{r}=n_{r}+1$ とする. 集合 $A$ の最後の作 業 $\rho_{l m}$ 抢よび作業 $y$ を元の集合に戻し, $x=\rho_{l m}$ とする．ステップ 2 に移る.

上記のアルゴリズムでステップ $5,6,7$ のいずれか のステップが実行されると，一つの作業が機械にスケ ジュールされる，ステップ6ではさらに一つの作業がバッ ファにスケジュールされる。これらのステップの 1 回の 実行を 1 回のスケジュール操作とよぶ. Fig.2のケース (a)，(b) 抢よび (c) はそれぞれステップ5，6 㧍よび 7 に 当たる.

ステップ 3 のデッドロック検知の手順を以下に示す. ステップ 1 空バッファがあれば，ステップ 3 へ移る.

$\underline{\text { ステップ } 2}$ 集合 $B$ の機械参照ジョブがすべて 集合 $O$ の 機械参照ジョブチェーン図のループチェー ン上にあるなら，デッドロックが発生した として，デッドロック検知を終了する.

ステップ 3 デッドロックがないとして, デッドロック 検知を終了する。

デコーディング手順のステップ 4 抢よび 7 の優先則に は種々の方法が考えられるが, 本研究では簡単に個体表 現上最も左の作業が所属するジョブを最優先とする。ま た，ステップ 6 の一定の基準は，ジョブ $q$ とジョブ $q$ を 
参照するジョブの処理中作業の完了時刻の遅い方を基準 值 $T_{L}$ とすれば，空バッファの中からバッファの空開始 時刻と $T_{L}$ との差の絶対值が最も小さいバッファをジョ ブ退避先バッファとするように定める.

上記の手順からわかるように，本デコーディング法は， 個体をセミアクティブスケジュールの空間へデコーディ ングする手法である。これはバッファ制限付き問題では バッファ無し問題と同様，最適解が必ずしもアクティブ スケジュール空間にないことが考えられるからである。

Fig. 3 は，(10) 式の個体がデコーディングによって生 成された実行可能スケジュールのガントチャートである。 このデコーディングには, 1 回のデッドロックが発生し ている。なお，このデコーディングの詳細なステップが 付録 2 に記してある。

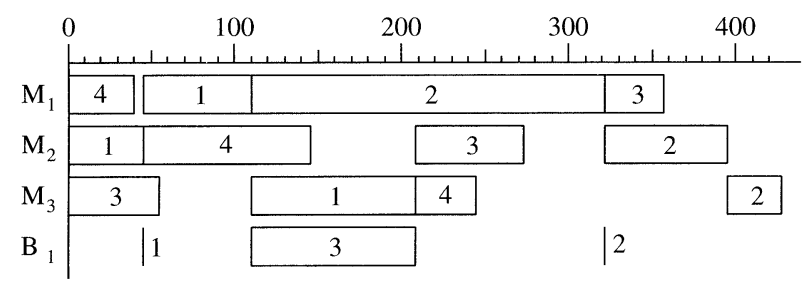

Fig. 3 The Gantt chart of a feasible solution given by (10)

\subsection{GA の全体アルゴリズム}

本論文はSteady-state GA[12] を用いる。その全体ア ルゴリズムを以下に示す.

ステップ 1 世代を $k=0$ とする. ランダムな作業順列 を持つ個体を $g$ 個生成し，それを初期個体 群 $\operatorname{Pop}[k]$ とする.

ステップ $2 g$ 個の個体からランダムに二つの個体を選 び出し，それを親とする。二つの親で交叉 を行い，二つの子個体を生成する。親を四 つの個体の内，最もよい二つの個体に置き 換える.同ステップを $g * p c$ 回繰り返す. ここに，pcは交叉確率である。

ステップ $3 \quad g$ 個の個体のおのおのについて, 確率 $p m$ で突然変異を行う。得られた子が親よりよ い適応度を持つなら，親に置き換わる。

ステップ $4=k_{\text {end }}$ ならばそれまでに得られている適 応度が最小の個体を問題の準最適解として 計算を終える，否ならば， $k=k+1$ として ステップ 2 へ戻る.

交叉則はオーダークロスオーバータイプの JOX[13]を 適用する. 突然変異則はスワップ (SWM)[13] とジョブ ベース変異則 $(J B M)[13]$ を交互に使用する．5.2 節のデ コーディング法は, 5.3 節のアルゴリズムのステップ 2 および 3 において個体の適応度計算に使用される。

\section{6. 本提案手法の性質}

本デコーディング方法には以下のような性質がある.
このうち性質 1 および 2 は, バッファ無し問題に対す るデコーディング方法 [8] における性質と同様に証明でき るので，ここでは性質 3 に対してのみその証明を述べる.

【性質 1】 $n_{r}^{*}$ を分に大きい值に設定すれば，任意 の個体 (遺伝子型表現) は実行可能解にデコーディングで きる。

【性質 2】任意のデコーディング可能な遺伝子型は唯 一の表現型にデコーディングされる.

【性質 3】任意のセミアクティブスケジュールには, デッドロックを起こさずに，デコーディングできる遺伝 子型が存在する。

（証明）任意のセミアクティブスケジュールに対して， まず以下のような個体を作成する.

作業をスケジュールにおける機械での処理開始時刻順 に並べる。もしも開始時刻が同一の作業があれば，機械 参照ジョブの次の処理予定作業の順番を先にする．ただ し，同開始時刻にバッファを使用開始するジョブがあれ ば，そのジョブを機械参照するジョブの次の処理予定作 業を, その他の作業より個体表現上の順番を先にする. このようにして得られた個体をデコーディングすると， デッドロックを起こすことなく, 当該のセミアクティブ スケジュールにデコーディングできる.

例えばFig. 3のスケジュールに対して，つぎのような 個体はデッドロックを起こさずにデコーディングできる.

$$
[4,1,3,4,1,1,2,4,3,3,2,2]
$$

すなわち, 作業 $\rho_{12}$ および $\rho_{42}$ の開始時刻は同一で, ジョ ブ 1 がジョブ 4 の機械参照ジョブであるが，その前にジョ ブ 1 がバッファを使用開始したので， $\rho_{42}$ を $\rho_{12}$ の左に 置けばよい. 同様なことを $\rho_{22}$ および $\rho_{33}$ に対してもい える。作業 $\rho_{32}$ および $\rho_{43}$ に関して, ジョブ 4 がジョブ 3 の機械参照ジョブなので, $\rho_{42}$ を左に置く必要がある.

\section{7. 計算結果}

本研究が扱う共通バッファ制限付き問題は他の文献で 扱われていないので, バッファ無し問題を扱った文献 $[7,8]$ で取り上げた問題にバッファの制限を付けて問題を作成 した. Table 1 にその問題のサイズを示すが，これらの 問題は文献 [14] で与えられたベンチマーク問題を修正し たものである。

GAの各パラメータについては，これまでの研究 $[7,8]$ で適当と思われる值を用い, $g=400, p c=1.0, p m=0.05$, $n_{r}^{*}=200$ とする。世代数 $k_{\text {end }}$ は, ss および $\mathrm{ft} 06$ が 200 世代, ft10が 1000 世代, la36が2000である. 各問題に 対してそれぞれ 20 回ずつ計算して結果を示す。計算に 用いたコンピュータは PentiumIII $850 \mathrm{MHz}$ のパソコン である. 計算時間は 1 回の計算で ft10 が約 15 分, la36 が約 1 時間 30 分程度である。

Fig. 4 およびFig. 5 はそれぞれ ft10およびla36の問題 に共通バッファが一つ存在すると設定したときの計算過 
Table 1 Benchmark problems

\begin{tabular}{|c|c|}
\hline Problem & Size $(N \times M)$ \\
\hline $\mathrm{ss}$ & $4 \times 3$ \\
\hline $\mathrm{ft} 06$ & $6 \times 6$ \\
\hline $\mathrm{ft} 10$ & $10 \times 10$ \\
\hline $\mathrm{la} 36$ & $15 \times 15$ \\
\hline
\end{tabular}

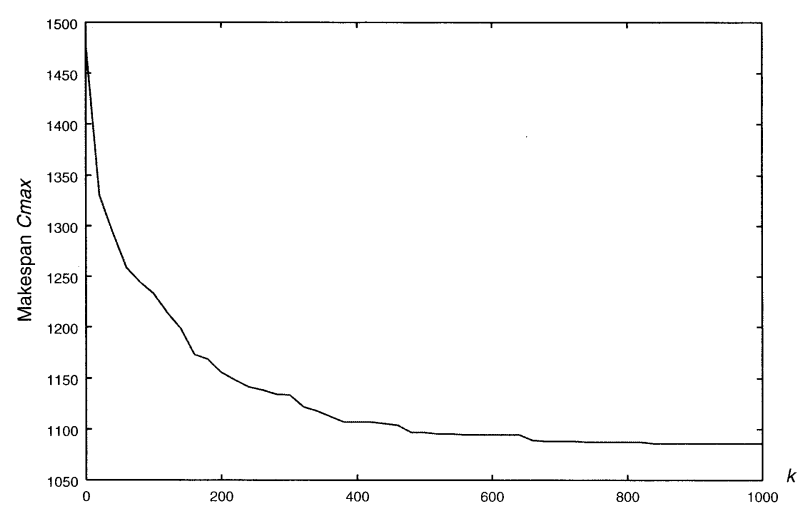

Fig. 4 Variation of makespan with generation (ft10, $B F=1)$

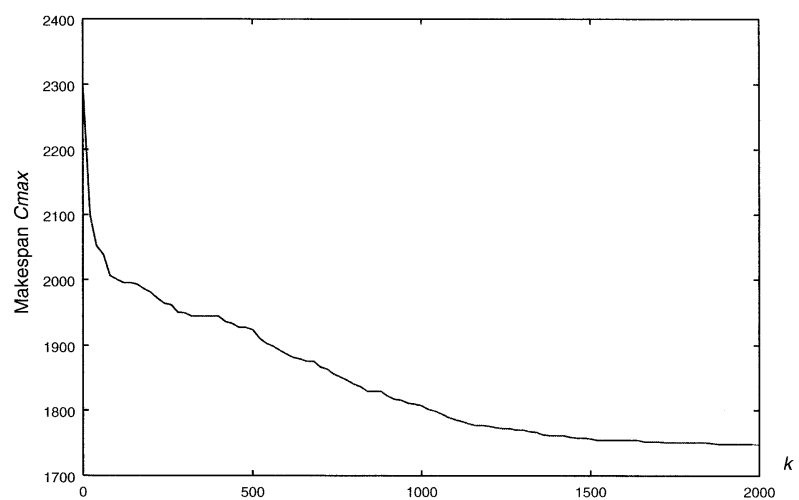

Fig. 5 Variation of makespan with generation (la36, $B F=1)$

程の一例を示す。同図に示す Makespanの值は各世代の 最良個体の值である。同図より世代数が増えるにつれ， 目的関数值が徐々に改善され，GA が良好に機能してい ることがわかる。

Fig. 6 は ft10 の問題において，バッファサイズ $B F$ を 変えて, 計算した準最適目的関数值の結果である。図中 の Average は20 回試行の平均值, Minimum は 20 回試 行の中の最良值を示す. 同図より，与えられるバッファの サイズ $B F$ が大きくなるにつれ，Makespanの目的関数 值が徐々に小さくなることがわかる。しかし，BFの值が 4 以上になると，それ以上 $B F$ を増やしても， Makespan の改善につながらないことがわかった。

Fig. 6 には単純多スタート局所探索法 (MLS 法) [15]を 用いた結果も示している. MLSに用いるデコーディング 法は本研究で提案した方法である。局所探索における近 傍の設定はJBM の突然変異則を使用した。スタートの

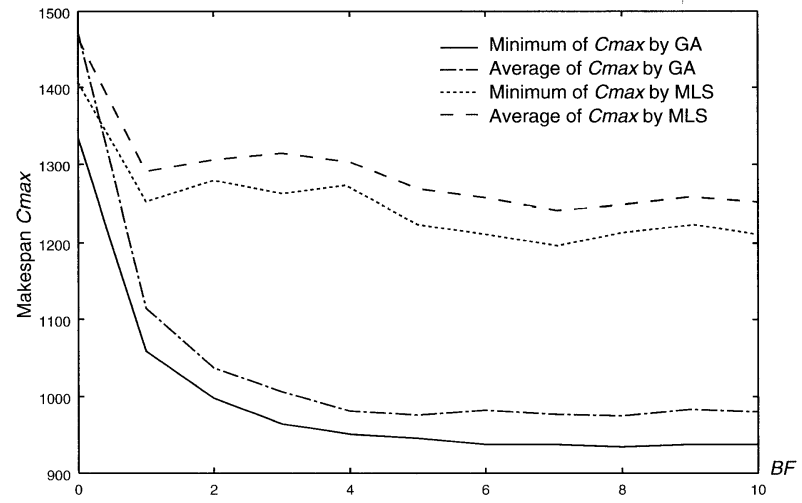

Fig. 6 Comparison of suboptimal makespan for various values of $B F$ between the proposed and MLS methods (ft10)

回数は 400 回であり, 目的関数の計算回数としては GA と同等な回数を掛けて計算を行った。図より MLS 法は 本研究で提案する GAより，明らかに悪い結果を示すこ とがわかった。なお，MLS法でこれ以上計算時間を増 やしても，目的関数值はあまり改善されなかった。さら にGA で得られた最終世代の解に MLS 法を適用したハ イブリッド型アルゴリズムでも計算を行ったが，GA 単 独で計算した結果と同程度か, それより優れた結果は得 られなかった。

Table 2 は本論文で扱った問題で $B F$ の值を種々に変 化させたときの結果を示し，さらにバッファ無しジョブ ショップ問題 $[3-8]$ および通常のバッファ制限無しジョブ ショップ問題 $[1,16]$ の結果と比較したものである.

同表において $B F=\infty$ のとき(通常のジョブショップ問 題) の結果は，それぞれの最適解である。一方， $B F<\infty$ の問題で本手法の結果を参照すると，問題 ss および $\mathrm{ft} 06$ に関して，それぞれ $B F \geq 1$ および $B F \geq 2$ で $B F=\infty$ に対する最適解を得ることができた。問題 $\mathrm{ft} 10$ に関し て， $B F \geq 6$ で $B F=\infty$ に対する最適解に近い良い解 $C_{\text {max }} \cong 930$ を得ることができた。一方，問題 la36に関 して, 本手法で得られる最良解は 1330 台に留まったが, これは本手法がセミアクティブスケジュールの解空間で 解を探索しているからであると考えられる．5章でも述心゙ たように，バッファ制限付き問題の最適解は必ずしもア クティブスケジュールではないので，通常のジョブショッ プ問題で用いる GT のアクティブデコーディング法より 悪い結果を得るのは，やむを得ないと考えられる。

さらに，本手法で計算したバッファ制約付きジョブ ショップ問題の結果は，すべて現在得られているバッ ファ無し問題 $(B F=0)$ およびバッファ制限無し問題 $(B F=\infty)$ の結果の中間にあることがわかった。このこ とは本手法の計算結果が適切であることを意味する.

本手法で $B F=0$ として計算した結果を，バッファ 無しジョブショップ問題に特化した方法 [8] で計算し た結果と比較すると， ss および $\mathrm{ft} 06$ の問題では同一 
Table 2 Comparison of $C_{\max }$ among various $B F$ values

\begin{tabular}{|c|c|c|c|c|}
\hline \multirow{2}{*}{$B F$} & \multicolumn{4}{|c|}{$C_{\max }(\mathrm{best} / \mathrm{mean})$} \\
\cline { 2 - 5 } & ss & $\mathrm{ft} 06$ & $\mathrm{ft} 10$ & $\mathrm{la} 36$ \\
\hline 0 & $512 / 512$ & $69 / 69$ & $1198 / 1242$ & $1950 / 2031$ \\
\hline 1 & $427 / 427$ & $60 / 60$ & $1059 / 1115$ & $1679 / 1750$ \\
\hline 2 & $427 / 427$ & $55 / 57$ & $998 / 1037$ & $1486 / 1715$ \\
\hline 3 & $427 / 427$ & $55 / 55$ & $964 / 1006$ & $1368 / 1445$ \\
\hline 4 & $427 / 427$ & $55 / 55$ & $951 / 981$ & $1357 / 1391$ \\
\hline 5 & - & $55 / 55$ & $946 / 976$ & $1357 / 1387$ \\
\hline 6 & - & $55 / 55$ & $937 / 982$ & $1334 / 1369$ \\
\hline 7 & - & - & $937 / 977$ & $1334 / 1367$ \\
\hline 8 & - & - & $934 / 975$ & $1331 / 1358$ \\
\hline 9 & - & - & $937 / 983$ & $1331 / 1362$ \\
\hline 10 & - & - & $937 / 980$ & $1331 / 1363$ \\
\hline 11 & - & - & - & $1334 / 1362$ \\
\hline 12 & - & - & - & $1331 / 1367$ \\
\hline 13 & - & - & - & $1337 / 1361$ \\
\hline 14 & - & - & - & $1334 / 1360$ \\
\hline 15 & - & - & - & $1331 / 1368$ \\
\hline$\infty$ & $427 /-$ & $55 /-$ & $930 /-$ & $1268 /-$ \\
\hline
\end{tabular}

Notes: The result for $B F=0$ was obtained from [3-8]. The result for $B F=\infty$ was obtained from[16].

の結果が得られたが, 問題 $\mathrm{ft} 10$ では本手法によると best $/$ mean $=1334 / 1472$ となり，[8] による方法より劣 る結果を得た。この理由は，バッファ無しジョブショッ プ問題では，スケジュール対象作業を機械参照ジョブ チェーンの終端作業に限定してデコーディングできるか ら，デッドロックの発生回数が大幅に減り，実行可能解 が得られやすいからである。同様な理由で問題 la36に おいては，本手法ではデッドロックの発生頻度が高くて, 実行可能解が得られなかった。 なお, 文献 [8]では, GA パラメータ $g, p c$ および $p m$ は本手法と同一值であるが, $k_{\text {end }}=2000$ と設定している。また， $n_{r}^{*}$ は $\mathrm{ss}, \mathrm{ft} 06$ およ び $\mathrm{ft} 10$ に対して 50 , la36に対して 100 と設定している.

計算結果のまとめとして，本提案手法はバッファ制限 付きジョブショップ問題に対して，優れた結果を示すこ とができた。なお，バッファ無しジョブショップ問題お よび通常のバッファ制限無しジョブショップ問題に対し ては，本手法で，それぞれ， $B F=0$ および $B F=\infty$ と パラメー夕設定をして適用するよりも, 問題特有の性質 を利用しておのおのの問題に提案された解法を用いる方 が望ましいと結論付けられる.ささらに, 規模の比較的大 きい問題でも，少ないバッファ数でバッファ制限無し問 題の最適值に近い目的関数值が得られた。

\section{8. おわりに}

本論文では，機械間で共通に使えるバッファに制限が ある共通バッファ制限付きジョブショップスケジューリ
ング問題を定義し, 問題特有のデッドロック状態を回避 したセミアクティブデコーディング方法を実装した遺伝 アルゴリズムを提案した。提案アルゴリズムの性質を分 析した後, いくつかのベンチマーク問題にバッファ制限 を付けて例題を作成し，計算を行った。

単純多スタート局所探索法 (MLS) を適用して, 提案 アルゴリズムと計算結果を比較した結果，本アルゴリ ズムはバッファ制限付き問題に対して，優れた結果を示 すことがわかった。なお，バッファ制限無し問題やバッ ファ無し問題に特有な万法で得られている結果と比較し た結果，本提案手法で得られた結果が適切であることが 示されたが，バッファなし問題やバッファ制限なし問題 には問題の性質を利用した特有な方法のほうが適するこ とが示された。さらに計算結果より，バッファ制限付き 問題においては，ある程度バッファを増やすことによっ て，目的関数值の改善が図れるが，一定の数のバッファ があれば，それ以上のバッファを増やしても，目的関数 值の改善には貢献しないことがわかった。

\section{謝辞}

本研究を遂行するにあたり，多大なご助言を頂いた京 都工芸繊維大学の木瀬洋教授ならびに飯間等助手に, 深 く感謝の意を表します。

\section{参考文献}

[1] M. Gen and R. Cheng: Genetic Algorithm \& Engineering Optimization, Wiley-Interscience (2000)

[2] N.G. Hall and C. Sriskandarajah: A survey of machine scheduling problems with blocking and no-wait in process; Operations Research, Vol. 44, No. 3 (1996)

[3] S.E. Ramaswamy and S.B. Joshi: Deadlock-free scheduling for automated manufacturing workstations; IEEE Trans. on Robotics and Automation, Vol. 12, No. 3, pp. 391-400 (1996)

[4] T. Liljenvell: Scheduling for production systems with limited buffer; Proc. of 1999 IEEE Intern. Conf. on Systems, Man and Cybernetics, pp. 469-474 (1999)

[5] T. Liljenvell: Benchmarking an algorithm for Petri net scheduling; Proc. of 2000 IEEE Intern. Conf. on Systems, Man and Cybernetics, pp. 3027-3032 (2000)

[6] Y. Mati, N. Rezg and X. Xie: A taboo search approach for deadlock-free scheduling of automated manufacturing systems; Journal of Intelligent Manufacturing, Vol. 12, No. 5/6, pp. 535-552 (2001)

[7] Y. Zhao and N. Sannomiya: A genetic algorithm to obtain dead-lock free schedules for no-buffer jobshop scheduling problems; Trans. of SICE, Vol. 37, No. 10, pp. 999-1001 (2001)

[8] 傅, 趙, 三宮：バッファ無しジョブショップスケジューリ ング問題に対する遺伝アルゴリズムの適用 ; システム制 御情報学会論文誌, Vol. 16, No. 5, pp. 234-241 (2003)

[9] C. Brizuela, Y. Zhao and N. Sannomiya: No-wait and 
blocking job-shops: Challenging problems for GA's; Proc. of 2001 IEEE Intern. Conf. on Systems, Man and Cybernetics, pp. 2349-2354 (2001)

[10] 玉置, 西川：バッファ容量を考慮したスケジューリング 問題のモデル化手法；計測自動制御学会論文集，Vol.31, No.7, pp. 933-940 (1995)

[11] 玉置, 西川：バッファ容量を考慮したスケジューリング 問題の解法; 計測自動制御学会論文集, Vol.31, No.8, pp. 1193-1201 (1995)

[12] D. Dumitrescu, B. Lazzerini, L.C. Jain and A. Dumitrescu: Evolutionary Computation, CRC Press LLC (2000)

[13] N. Sannomiya, H. Iima, K. Suzuki and Y. Kobayashi: Genetic algorithm approach to a scheduling problem for a complex manufacturing system; Proc. of 8 th IFAC Symp. on Large Scale Systems; Theory $\&$ application, pp. 271-276 (1998)

[14] J.E. Beasly: OR-library: Distributing test problems by electronic mail; Journal OR Society, Vol. 41, No. 11, pp. 1069-1072, http://mscmga.ms.ic.ac.uk/ info.html (1990)

[15] 柳浦, 茨木 : 組合せ最適化 (メ夕戦略を中心として), 朝 倉書店 (2001)

[16] L. Michel and P. V. Hentenryck: Job-Shop Scheduling in Localizer; Brown University Technical Report CS-98-03, April (1998)

\section{付 録}

付録 1. 問題例 ss のパラメータ

問題例 $\mathrm{ss}[3]$ の $\mu_{i j}, t_{i j}$ の值を Table A1 に示す.

Table A1 Problem parameters of ss

\begin{tabular}{|c|c|c|c|c|c|c|}
\hline & \multicolumn{3}{|c|}{$\mu_{i j}$} & \multicolumn{3}{|c|}{$t_{i j}$} \\
\hline J & 1 & 2 & 3 & 1 & 2 & 3 \\
\hline 1 & 1 & 2 & 3 & 40 & 100 & 36 \\
\hline 2 & 2 & 1 & 3 & 45 & 65 & 98 \\
\hline 3 & 1 & 2 & 3 & 212 & 73 & 32 \\
\hline 4 & 3 & 2 & 1 & 55 & 65 & 35 \\
\hline
\end{tabular}

\section{付録 2. Fig.3 の説明}

個体表現 (10) 式が5.2 節のデコーディング方法によっ て, Fig. 3 のスケジュールにデコーディングされる手順 は以下の通りである。

なお，下記の各段は 5.2 節のデコーディング方法の 1 回のスケジュール操作に当たる。ただし，6.1の段は デッドロック発生時の 5.2 節のステップ 10 の操作に当た る.さらに $\rho_{11} \rightarrow A$ の表記は $\rho_{11}$ が集合 $A$ にセットされ ることを表す.

1. $A=\emptyset, B=\emptyset, C=\left\{\rho_{11}, \rho_{41}, \rho_{42}, \rho_{31}, \rho_{12}, \rho_{21}, \rho_{13}\right.$, $\left.\rho_{43}, \rho_{32}, \rho_{33}, \rho_{22}, \rho_{23}\right\}, O=\left\{\rho_{11}, \rho_{41}, \rho_{31}, \rho_{21}\right\}, x=$ NULL $\Longrightarrow \rho_{11} \rightarrow A$
2. $A=\left\{\rho_{11}\right\}, B=\emptyset, C=\left\{\rho_{41}, \rho_{42}, \rho_{31}, \rho_{12}, \rho_{21}, \rho_{13}\right.$, $\left.\rho_{43}, \rho_{32}, \rho_{33}, \rho_{22}, \rho_{23}\right\}, O=\left\{\rho_{41}, \rho_{31}, \rho_{12}, \rho_{21}\right\}, x=$ NULL $\Longrightarrow \rho_{41} \rightarrow A$

3. $A=\left\{\rho_{11}, \rho_{41}\right\}, B=\emptyset, C=\left\{\rho_{42}, \rho_{31}, \rho_{12}, \rho_{21}, \rho_{13}\right.$, $\left.\rho_{43}, \rho_{32}, \rho_{33}, \rho_{22}, \rho_{23}\right\}, O=\left\{\rho_{42}, \rho_{31}, \rho_{12}, \rho_{21}\right\}, x=$ NULL $\Longrightarrow \rho_{12} \rightarrow B, \quad \rho_{42} \rightarrow A$

4. $A=\left\{\rho_{11}, \rho_{41}, \rho_{42}\right\}, B=\left\{\rho_{12}\right\}, C=\left\{\rho_{31}, \rho_{21}, \rho_{13}\right.$, $\left.\rho_{43}, \rho_{32}, \rho_{33}, \rho_{22}, \rho_{23}\right\}, O=\left\{\rho_{31}, \rho_{12}, \rho_{21}, \rho_{43}\right\}, x=$ NULL $\Longrightarrow \rho_{31} \rightarrow A$

5. $A=\left\{\rho_{11}, \rho_{41}, \rho_{42}, \rho_{31}\right\}, B=\left\{\rho_{12}\right\}, C=\left\{\rho_{21}, \rho_{13}\right.$, $\left.\rho_{43}, \rho_{32}, \rho_{33}, \rho_{22}, \rho_{23}\right\}, O=\left\{\rho_{12}, \rho_{21}, \rho_{43}, \rho_{32}\right\}, x=$ NULL

$\Longrightarrow \rho_{12} \rightarrow A$

6. $A=\left\{\rho_{11}, \rho_{41}, \rho_{42}, \rho_{31}, \rho_{12}\right\}, B=\emptyset, C=\left\{\rho_{21}, \rho_{13}\right.$, $\left.\rho_{43}, \rho_{32}, \rho_{33}, \rho_{22}, \rho_{23}\right\}, O=\left\{\rho_{21}, \rho_{13}, \rho_{43}, \rho_{32}\right\}, x=$ NULL $\Longrightarrow \rho_{13} \rightarrow B, \quad \rho_{21} \rightarrow A$

6.1. $A=\left\{\rho_{11}, \rho_{41}, \rho_{42}, \rho_{31}, \rho_{12}, \rho_{21}\right\}, B=\left\{\rho_{13}\right\}, C=$ $\left\{\rho_{43}, \rho_{32}, \rho_{33}, \rho_{22}, \rho_{23}\right\}, O=\left\{\rho_{13}, \rho_{43}, \rho_{32}, \rho_{22}\right\}, x=$ NULL $\Longrightarrow$ デッドロック発生 $\Longrightarrow A=A-\left\{\rho_{21}\right\}, B=B-$ $\left\{\rho_{13}\right\}, C=C+\left\{\rho_{21}, \rho_{13}\right\}, x=\rho_{21}$

7. $A=\left\{\rho_{11}, \rho_{41}, \rho_{42}, \rho_{31}, \rho_{12}\right\}, B=\emptyset, C=\left\{\rho_{21}, \rho_{13}\right.$, $\left.\rho_{43}, \rho_{32}, \rho_{33}, \rho_{22}, \rho_{23}\right\}, O=\left\{\rho_{21}, \rho_{13}, \rho_{43}, \rho_{32}\right\}, x=\rho_{21}$

$\Longrightarrow \rho_{32} \rightarrow B, \quad \rho_{13} \rightarrow A, \quad x=\mathrm{NULL}$

8. $A=\left\{\rho_{11}, \rho_{41}, \rho_{42}, \rho_{31}, \rho_{12}, \rho_{13}\right\}, B=\left\{\rho_{32}\right\}, C=\left\{\rho_{21}\right.$, $\left.\rho_{43}, \rho_{33}, \rho_{22}, \rho_{23}\right\}, O=\left\{\rho_{21}, \rho_{43}, \rho_{32}\right\}, x=\mathrm{NULL}$

$\Longrightarrow \rho_{21} \rightarrow A$

9. $A=\left\{\rho_{11}, \rho_{41}, \rho_{42}, \rho_{31}, \rho_{12}, \rho_{13}, \rho_{21}\right\}, B=\left\{\rho_{32}\right\}$, $C=\left\{\rho_{43}, \rho_{33}, \rho_{22}, \rho_{23}\right\}, O=\left\{\rho_{43}, \rho_{32}, \rho_{22}\right\}, x=$ NULL

$\Longrightarrow \rho_{43} \rightarrow A$

10. $A=\left\{\rho_{11}, \rho_{41}, \rho_{42}, \rho_{31}, \rho_{12}, \rho_{13}, \rho_{21}, \rho_{43}\right\}, B=\left\{\rho_{32}\right\}$, $C=\left\{\rho_{33}, \rho_{22}, \rho_{23}\right\}, O=\left\{\rho_{32}, \rho_{22}\right\}, x=$ NULL

$\Longrightarrow \rho_{32} \rightarrow A$

11. $A=\left\{\rho_{11}, \rho_{41}, \rho_{42}, \rho_{31}, \rho_{12}, \rho_{13}, \rho_{21}, \rho_{43}, \rho_{32}\right\}, B=\emptyset$, $C=\left\{\rho_{33}, \rho_{22}, \rho_{23}\right\}, O=\left\{\rho_{33}, \rho_{22}\right\}, x=$ NULL

$\Longrightarrow \rho_{33} \rightarrow A$

12. $A=\left\{\rho_{11}, \rho_{41}, \rho_{42}, \rho_{31}, \rho_{12}, \rho_{13}, \rho_{21}, \rho_{43}, \rho_{32}, \rho_{33}\right\}$, $B=\emptyset, C=\left\{\rho_{22}, \rho_{23}\right\}, O=\left\{\rho_{22}\right\}, x=\mathrm{NULL}$

$\Longrightarrow \rho_{22} \rightarrow A$

13. $A=\left\{\rho_{11}, \rho_{41}, \rho_{42}, \rho_{31}, \rho_{12}, \rho_{13}, \rho_{21}, \rho_{43}, \rho_{32}, \rho_{33}, \rho_{22}\right\}$, $B=\emptyset, C=\left\{\rho_{23}\right\}, O=\left\{\rho_{23}\right\}, x=$ NULL

$\Longrightarrow \rho_{23} \rightarrow A$

14. $A=\left\{\rho_{11}, \rho_{41}, \rho_{42}, \rho_{31}, \rho_{12}, \rho_{13}, \rho_{21}, \rho_{43}, \rho_{32}, \rho_{33}, \rho_{22}\right.$, $\left.\rho_{23}\right\}, B=\emptyset, C=\emptyset, O=\emptyset, x=\mathrm{NULL}$

$\Longrightarrow$ デコーディング終了

上記より (10) 式は 5.2 節のデコーディング方法によっ て, 13 回のスケジュール操作で Fig. 3 のスケジュール にデコーディングされた. 
